\title{
発声時喉頭所見を基にした機能性発声障害の診断と音声治療の効果
}

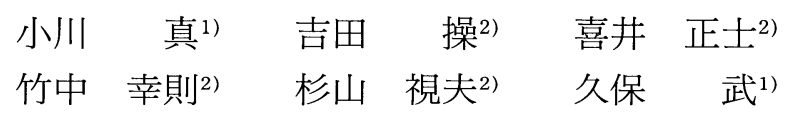

\begin{abstract}
要 約：Koufman \& Blalock の喉頭所見による分類に従って, 機能性発声障害を, 声門間 隙が認められるものと声門上部圧迫が認められるものに 2 分し, 異なる音声治療プロトコール, および異なる評価スコアを用いて音声治療効果を検討した。プロトコールとして，前者には(1) 咳払い，(2)口を閉じた咳払い，(3)八ミング，(4)開口の順で，後者には(1)八ミング，(2)ピッチを 高くして声の焦点を鼻根部に意識, (3)開口の順で行い, 無効時にあくび-ため息法を付加した. それぞれに対し「達成度スコア」および「MTD スコア」にて評価し，ともに音声治療経過中に スコアの経時的減少が認められた。 以上の結果より，ともに音声治療が有効であることが示さ れ, 機能性音声障害に対して喉頭所見を基にした分類を行うことは意義があると考えられた.
\end{abstract}

索引用語：機能性発声障害，発声時喉頭所見，声門間隙，声門上部圧迫，音声治療

\section{Diagnosis of Functional Voice Disorders Based on Laryngeal Findings during Phonation and Efficacy of Voice Therapy}

\author{
Makoto Ogawa1), Misao Yoshida', ${ }^{2)}$ Tadashi Yoshii ${ }^{2)}$, Yukinori Takenaka ${ }^{2)}$, \\ Yoshio Sugiyama ${ }^{2)}$ and Takeshi Kubo ${ }^{1)}$
}

\begin{abstract}
We divided cases with functional voice disorders into type 1 with glottal chink and type 2 with supraglottic contraction, according to Koufman and Blalock classification on the basis of laryngeal findings during phonation. Different protocols of voice therapy and scoring methods for evaluation were adapted for each type. For the protocol of voice therapy for the former type, step facilitations consisted of 1) throat clearing, 2) throat clearing with the mouth closed, 3) humming, and 4) mouth opening performed to induce sustained vowel phonation. Regarding the latter type, 1) humming, 2) raising the pitch to feel the 'focus' in the nasal dorsum, and 3) mouth opening were performed progressively, augmented by the yawn-sigh method when facilitations were ineffective. To assess severity, 'accomplishment scores' and 'MTD scores' were used, respectively, and in both instances gradual decreases were seen during the course of voice therapy. The results demonstrated the effectiveness of voice therapy against these types of functional voice disorders and suggested the need for classification of functional
\end{abstract}

\footnotetext{
大阪大学大学院耳鼻咽喉科 ${ }^{12}:$ T565-0871 大阪府吹田市山田丘 2 番 2 号

公立学校共済組合近畿中央病院耳鼻咽喉科 $\left.{ }^{2}\right):$ T664-8533 兵庫県伊丹市車塚 3 丁目 1 番地

${ }^{1}$ Department of Otorhinolaryngology, Osaka University School of Medicine: 2-2, Yamadaoka, Suita, Osaka 565-0871

${ }^{2}$ Department of Otorhinolaryngology, Kinki Central Hospital of Mutual Aid Association of Public School Teachers: 3-1,

Kurumazuka, Itami, Hyogo 664-8533

2006 年 12 月 4 日受稿 2007 年 4 月 19 受理
} 
dysphonia based on laryngeal findings.

Key words: functional voice disorders, laryngeal findings, glottal chink, supraglottic contraction, voice therapy

\section{はじめに}

声带を含む喉頭の器質的病変によって生じる音声障 害を「器質的音声障害」と呼ぶ。一方で, 発声器官に 明らかな異常がないのに発声障害を呈するものを「機 能性発声 (音声) 障害」と呼ぶ゙1). 前者に多様な疾患が 含まれるように，後者もまた，心因性失声症や過緊張 性発声障害などのさまざまな疾患が含まれている。

耳鼻咽喉科診療での音声障害の診断においては，音 声所見のみでなく喉頭所見が重要な手掛りとなる。器 質的音声障害については, 主に声带の器質的病変の探 索が重要となることに異論はないであろう。一方の機 能性発声障害の喉頭所見については, Koufman \& Blalock ${ }^{2,3}$ 抢よび Morrison \& Rammage ${ }^{4)}$ が詳細に記
述している，特に前者に扔いては，機能性発声障害に おいて認められる代表的な 4 種類の発声時喉頭所見を 提示している。図 1 はこれらに相当する喉頭所見画像 を示したものである（文献５より一部を改変して転 載)。これらの喉頭所見は, type I における失声あるい は気息性嗄声，一方，type II-IV における粗糙性嗄声 という特徵的な異常音声の生成に深く関連していると 考えられ, それぞれ本邦の心因性失声症, 過緊張性発 声障害に相当するものと考元られる。

機能性発声障害の治療として, 音声治療の有効性が 報告されている ${ }^{3,6,7)}$. Kotby ら ${ }^{6)}$ は，機能性発声障害を 含むさまざまな音声障害疾患に対するアクセント法の 有効性を報告している. Roy ら》は, 機能性発声障害症 例に対する喉頭マッサージの有効性を示している。し
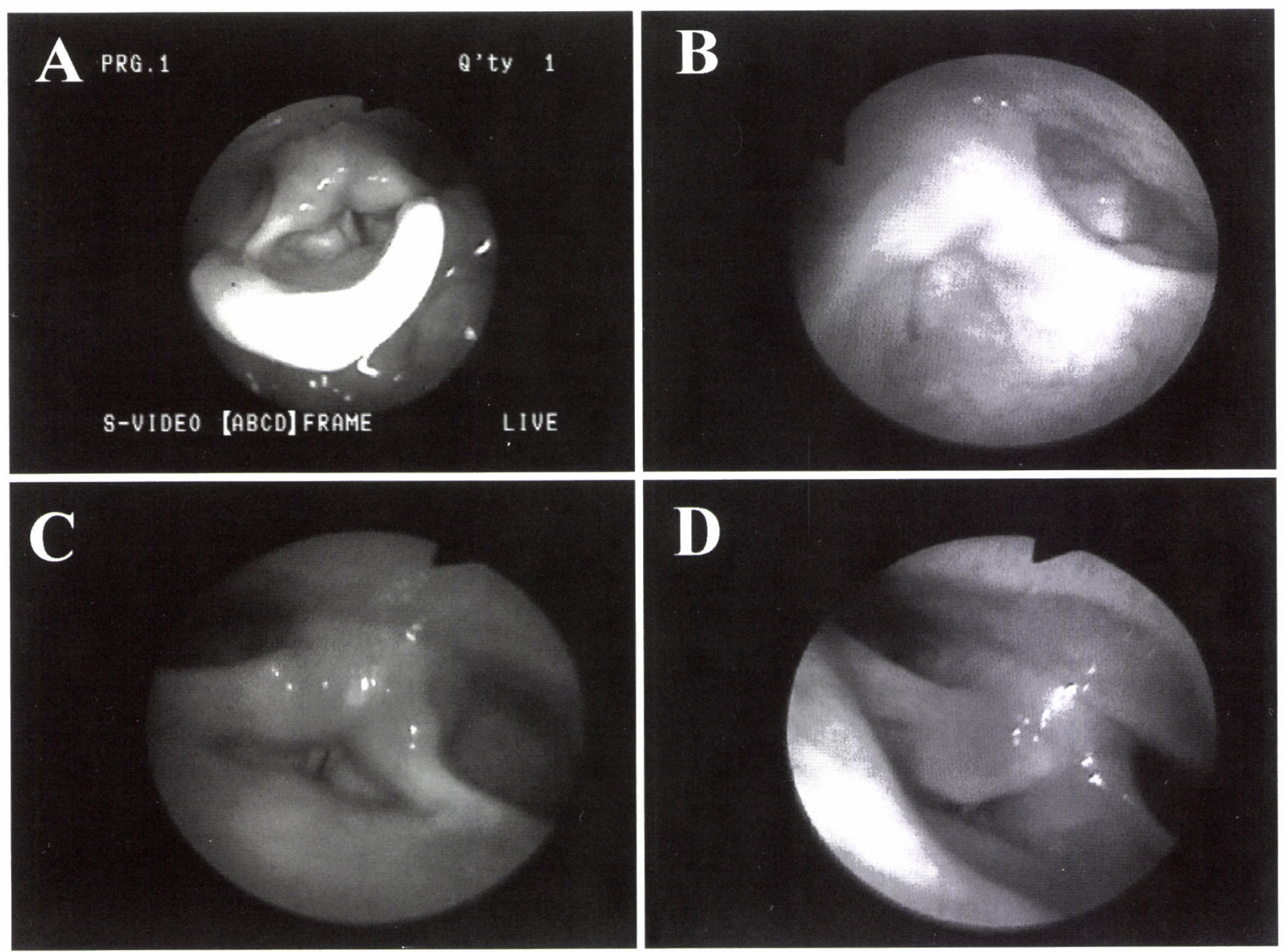

図 1 Koufman \& Blalock による機能性発声障害の喉頭所見による分類

A : type I. 声門間隙. B : type II. 仮声带の接近. C : type III. 披裂喉頭蓋括約部の前後方向の中等度短縮. D：type IV．披裂唉頭蓋括約部の完全閉鎖（文献 5 より一部改変し転載）。 
かしながら，これらの検討において種々の問題点が含 まれている. Koufman \& Blalock の報告3に扔いて は，機能性発声障害の型別の治療成績を述べているも のの，使用された音声治療手技について明確に記載さ れていない.また，Kotby らのの報告においては，多種 の疾患を含む症例群に対して，同様の治療手技として アクセント法を行い, 聴覚的スコアと空気力学的指標 によって評価を行っているが，多様な疾患に対して画 一的な評価を行っている点で問題があると思われる。

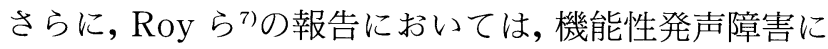
対する喉頭マッサージに有効性について知覚的スコア と音響分析により検討しているが，対象症例が 1 人を 除いてすべて女性であり，すべてが心的葛藤を伴って いることから，ある特定の型の機能性発声障害のみを 対象としていることが疑われる。このように，これま で機能性発声障害に対する音声治療の効果を検討した 報告にはさまざまな問題点が含まれている。

そこで今回われわれは，(1) 機能性発声障害を発声 時喉頭所見により型別に分けて検討する，(2) 型に適 した音声治療の手技を使用する，(3) 型に適した評価 方法を使用することを試みた。すなわち，機能性発声 障害をその発声時喉頭所見より, type I の喉頭所見お よび失声を認めるものと, type II-IV の喉頭所見およ び粗鈢性嗄声を認めるものに分類し，それぞれに対し て異なった音声治療のプロトコールを用い，さらに， それぞれ異なる重症度の評価法を使用することによ り，音声治療の有効性について検討を行った，重症度 評価に関して，前者においては使用した音声治療プロ トコール達成度に基づくスコアを，後者においては喉 頭ファイバースコープ下の発声時喉頭所見における喉 頭過閉鎖の程度に基づくスコアを用いた。その結果， 両スコアともに音声治療経過中に経時的減少が認めら れた. 以上より，それぞれの型の機能性発声障害に対 する音声治療の有効性が示され，機能性発声障害を発 声時喉頭所見により分類する意義が示された。

\section{対象と方法}

対象は，(A) 平成 14 年 4 月 1 日から平成 18 年 3 月 31 日までの間に近畿中央病院耳鼻咽喉科を受診し, type I の喉頭所見および失声を認めた症例, および (B)平成 14 年 4 月 1 日から平成 16 年 3 月 31 日まで の間に近畿中央病院耳鼻咽喉科を受診し, type II-IV の喉頭所見および粗糙性嗄声を認めた症例で，少なく とも 1 回の音声治療が施行されたものである. 対象症 例数は，それぞれ 14 例および 24 例であった。発声時
喉頭所見に関しては，鼻腔内を $1 \%$ キシロカインにて 十分に麻酔し, 楽な姿勢, 楽なピッチで, 力を抜いて, 数秒間「エー」の発声を指示したときのものを用いた。 脳梗塞を含めて神経学的疾患の既往のある症例, 声帯 萎縮あるいは声帯溝症を含む声帯病変を伴う症例も除 外した。前者に関しては，咳払い時には喉頭閉鎖が認 められることを確認することにより両側声帯固定を除 外した。後者については，喉頭内腔の狭窄が間歇的に 生じて，持続母音発声時よりも話声時に増悪する傾向 のあるものは内転型病攣性発声障害と診断し, 検討対 象としなかった．対象症例の年齢・性別・病悩期間を 含むプロフィールを表 1 に示す。音声障害に対する治 療としては音声治療のみを行い，この間薬物療法は一 切行わなかった。

音声治療の方法については，原則として 1 週間に 1 回の頻度で, 1 回につき 30 分, 同一の言語聴覚士 1 名 (M.Y.)により施行された。その間，原則として 4 週間 に 1 回, 耳鼻咽喉科医師が診察を行った。実際の音声 治療のプロトコールとして, (A) に対しては, 表 2 のプ ロトコールを達成するごとに順に 1 段階ずつ施行して いった。一方（B）に対するプロトコールとしては，表 3 に示すような声の配置法8を取り入れた一連の誘導 を毎回行い，無効時にはあくび-ため息法9を行った後 に再び上記の一連の誘導を行った。

治療の評価方法に関して，(A)に扔いては, 初診時に 有響音発声が不可能，あるいは発声の行為自体が不可 能なことがあるため, 音声所見による評価は困難であ ると考えられた。したがって，音声治療プロトコール の到達度によるスコアを用いた（表 2 )。（B）において は, 発声時喉頭所見, すなわち喉頭過閉鎖の程度にて 評価を行う MTD スコア5,10)を用いた。この方法は, 声 門上部圧迫について, 仮声帯部における横方向の圧迫 と披裂喉頭蓋括約部における前後方向の圧迫のそれぞ れについて, 圧迫なし：0 点, 圧迫はあるが接触なし： 1 点, 接触 (完全閉塞) : 2 点とスコア化する Stager 法 ${ }^{11}$ の変法であり, Stager 法の 2 つのスコアの和に, ストロボスコピーによる声帯振動異常の有無の 1 点を 足したものである.

\section{結果}

(A) type Iの㬋頭所見および失声を認めた機能性失 声症において, 達成度スコアを用いて治療経過に伴う 変化を示したものが図 2 である.初回評価時において, 㖩き声による会話が可能で咳払いが可能なものが 11 例, 無言症で咳払いが困難であったものが 3 例あった。 
表 1 対象症例のプロフィール

\begin{tabular}{|c|c|c|c|c|c|c|c|}
\hline No. & 氏名 & 年齢 & 性別 & 発声時喉頭所見の型 & 病悩期間 & 先行するエピソード & 音声酷使 \\
\hline 1 & S.M. & 30 & $\mathrm{~F}$ & I & 2 週間 & 生活上のトラブル & 無 \\
\hline 2 & R.M. & 14 & $\mathrm{M}$ & I & 2 力月 & 生活上のトラブル & 無 \\
\hline 3 & S.Y. & 81 & $\mathrm{~F}$ & I & 6 力月 & 無 & 無 \\
\hline 4 & S.K. & 45 & $\mathrm{~F}$ & I & 3 力月 & 生活上のトラブル & 無 \\
\hline 5 & I.S. & 36 & $\mathrm{~F}$ & I & 1 週間 & 無 & 無 \\
\hline 6 & M.F. & 57 & $\mathrm{~F}$ & I & 1 年 & 生活上のトラブル & 無 \\
\hline 7 & M.N. & 41 & M & I & 1 力月 & 生活上のトラブル & 無 \\
\hline 8 & T.F. & 41 & $\mathrm{~F}$ & I & 1 力月 & 生活上のトラブル & 無 \\
\hline 9 & C.U. & 25 & $\mathrm{~F}$ & I & 10 力月 & 無 & 無 \\
\hline 10 & S.T. & 65 & $\mathrm{~F}$ & I & 2 週間 & 生活上のトラブル & 無 \\
\hline 11 & R.U. & 19 & $\mathrm{~F}$ & I & 1 年 & 生活上のトラブル & 無 \\
\hline 12 & M.S. & 26 & $\mathrm{~F}$ & I & 1 年 & 生活上のトラブル & 無 \\
\hline 13 & M.T. & 35 & $\mathrm{~F}$ & I & 4 力月 & 無 & 無 \\
\hline 14 & Y.A. & 33 & $\mathrm{~F}$ & I & 1 力月 & 生活上のトラブル & 無 \\
\hline 15 & N.K. & 37 & M & II & 1 年半 & 無 & 無 \\
\hline 16 & K.K. & 69 & M & II & 3 力月 & 無 & 無 \\
\hline 17 & K.M. & 70 & M & II & 8 力月 & 感冒様症状 & 無 \\
\hline 18 & A.T. & 50 & M & $\mathrm{II}+\mathrm{III}$ & 1 力月 & 無 & 有 \\
\hline 19 & N.H. & 32 & M & $\mathrm{II}+\mathrm{III}$ & 1 年半 & 無 & 有 \\
\hline 20 & H.T. & 63 & M & II + III & 不明 & 無 & 無 \\
\hline 21 & O.T. & 65 & M & $\mathrm{II}+\mathrm{III}$ & 数年 & 無 & 有 \\
\hline 22 & I.T. & 66 & M & $\mathrm{II}+\mathrm{III}$ & 1 力月 & 感冒様症状 & 無 \\
\hline 23 & S.K. & 66 & M & $\mathrm{II}+\mathrm{III}$ & 2 力月 & 悪性腫瘍入院加療中 & 無 \\
\hline 24 & N.I. & 68 & M & $\mathrm{II}+\mathrm{III}$ & 1 年 4 力月 & 無 & 無 \\
\hline 25 & H.M. & 71 & M & $\mathrm{II}+\mathrm{III}$ & 1 力月 & 悪性腫瘍入院加療中 & 無 \\
\hline 26 & M.Y. & 71 & $\mathrm{M}$ & $\mathrm{II}+\mathrm{III}$ & 1 年 & 無 & 無 \\
\hline 27 & M.I. & 74 & M & II + III & 1 週間 & 無 & 有 \\
\hline 28 & Y.S. & 74 & $\mathrm{M}$ & II + III & 6 年 & 無 & 無 \\
\hline 29 & N.S. & 75 & M & II + III & 6 力月 & 無 & 有 \\
\hline 30 & N.H. & 76 & M & III & 1 年 & 感冒様症状 & 無 \\
\hline 31 & H.J. & 81 & $\mathrm{M}$ & IV & 2 年 & 感冒様症状 & 無 \\
\hline 32 & S.Y. & 72 & M & IV & 1 力月 & 感冒様症状 & 無 \\
\hline 33 & H.Y. & 73 & M & IV & 3 力月 & 感冒様症状 & 無 \\
\hline 34 & T.T. & 41 & M & IV & 1 力月 & 無 & 無 \\
\hline 35 & M.Y. & 43 & M & IV & 6 力月 & 無 & 有 \\
\hline 36 & W.M. & 55 & M & IV & 6 力月 & 無 & 有 \\
\hline 37 & T.T. & 60 & M & IV & 3 力月 & 無 & 有 \\
\hline 38 & M.S. & 60 & M & IV & 2 力月 & 感冒様症状 & 無 \\
\hline
\end{tabular}

音声治療経過中全例において達成度スコアは経時的減 少を示し, 音声治療開始後 4 週の時点で全例において 持続母音発声が可能となった。 しかしながら, 到達度 スコアが $1 ， 2$ でとどまり音声治療が 8 週以上にわた る症例が 3 例認められた。

一方，(B) type II-IVの喉頭所見および粗糙性嗄声 を認めた過緊張性発声障害に扔いては，文献 5 にてす でに報告しているため，MTD スコアの変化のみを図 3 に提示した. 全症例において MTD スコアの経時的 減少が認められた。

\section{考察}

これまで，機能性音声障害に対する音声治療の有効 性が報告されている3,5-7). しかしながら，これらの検討 において，1) 使用した音声治療の手技について詳細に 記載されていない，2)さまざまな型の機能性音声障害 を対象にしているにもかかわらず，同一の音声治療法 のみを使用し，同一の評価方法を使用している，3)対 象とする機能性発声障害の型が限られているなどの問 題点が認められた。したがって，今回の検討において は，1）診断および型分類に Koufman \& Blalock の喉 頭所見の分類を使用した。2) 型別に異なる音声治療プ 
表 2 Type I の機能性音声障害に対する音声 治療のプロトコールと到達度スコア

音声治療のプロトコール

下記について，1段階ずつ順に達成していく (1)咳払い

(2)閉口での咳払い

(3)ハミング

(4)そのまま開口

(5)「ナ」「マ」で始まる単語への般化

(6)会話声への般化

到達度スコア

Score 6: 無言/咳払い誘導不可

Score 5: 咳払い誘導可能

Score 4: ハミング誘導可能

Score 3: 持続母音発声可能

Score 2: 単語発声可能

Score 1: 会話可能（非流暢）

Score 0: 会話可能（流暢）

表 3 Type II -IVの機能性発声障害に対する音声治療の プロトコールと治療前後の発声時喉頭所見の変化

\section{以下を連続して誘導する}

(1)ハミング

(2)ピッチを高くして鼻根部に焦点を意識

(3)焦点を保ったまま開口

上記の方法が有効であるときは

あくびーため息法を行った後に再び上記を行う

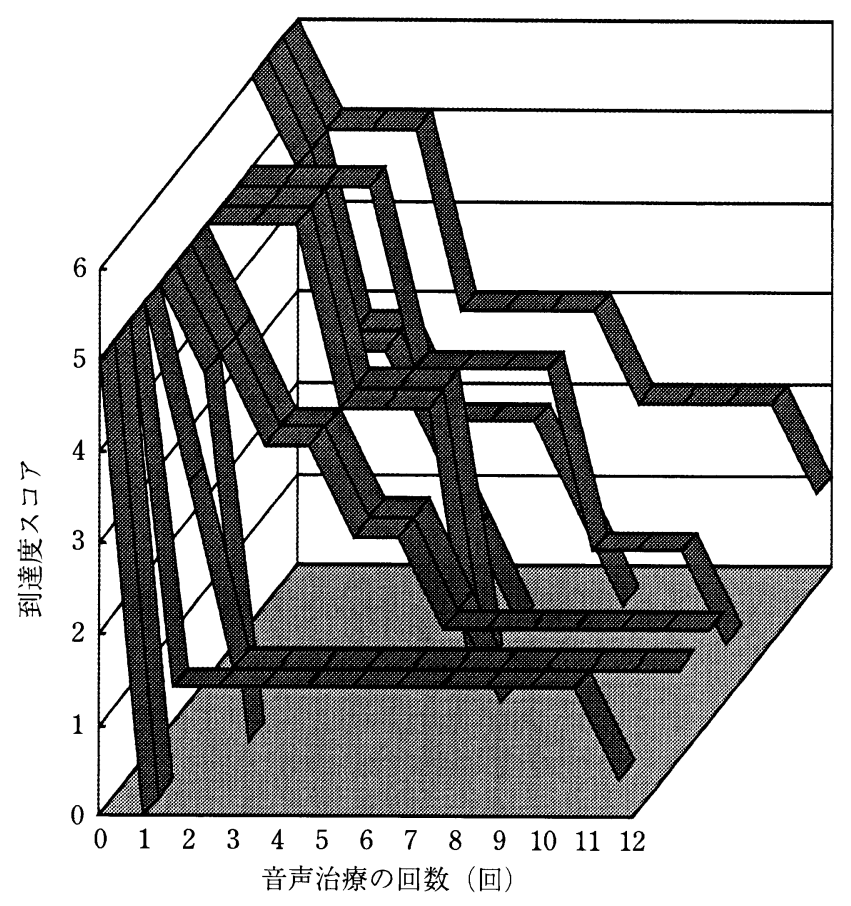

図 2 Type I の機能性発声障害における音声治療経過中の 到達度スコアの変化

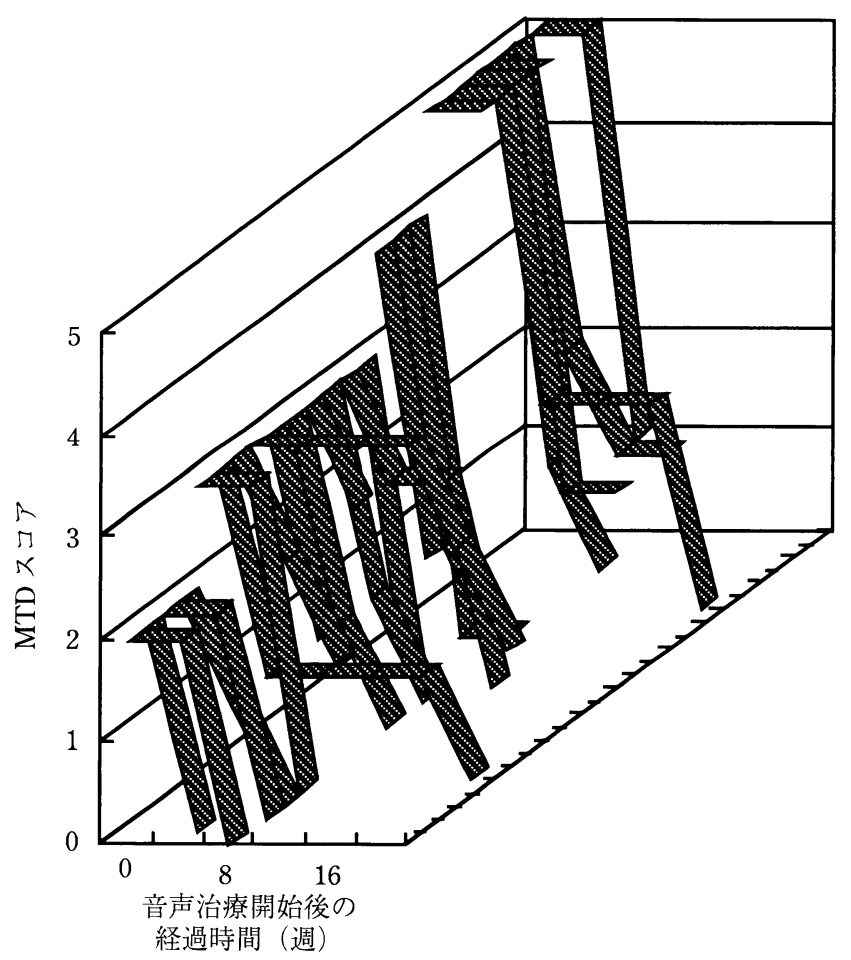

図 3 Type II-IVの機能性発声障害における治療経過中の MTD スコアの変化（文献 5 より転載）

ロトコールを用いて, 型別に音声治療の方法を統一し た３）型別に，簡易なスコアを用いて評価を行った。 その結果, 両者ともに経時的なスコアの減少が認めら れた。その結果, 両スコアともに音声治療経過中に経 時的な減少が認められた。

機能性発声障害の喉頭所見に関しては, Koufman \& Blalock の分類 ${ }^{3)}$ 用いた. Morrison \& Rammage ${ }^{4)}$ も また, 発声時声門間隙, 仮声帯過内転, および声門上 部の前後方向の圧迫を機能性発声障害の喉頭所見とし て記述している. 前者においては，エピソードを基に した機能性発声障害の分類についても記述しており, 両者間の関連性について, 心因性および反復性失声症 においては type I が, 音声酷使による機能性発声障害 においてはtype II-IVが多く認められるとしてい る ${ }^{3)}$. 後者においても, 転換型失声症では, 咳嗽時には 声帯が内転するにもかかわらず発声時には正中まで寄 り切らないこと, また声門上部の前後径短縮が音声酷 使と関連があることを記述している4). 今回の対象症 例において, type I を認めた症例で先行するエピソー ドとして生活上のトラブルが認められたが，他ではほ とんどそのような症例が認められなかったこと, type II+III および type IV が認められた症例で音声酷使 の既往を有するものが多く認められたが, type I を認 めた症例では認められなかったことは, これらの報告 
に一致する.さらに, 今回の対象症例で type II と type III とが混在して認められる症例が多かったことを考 慮すると, 今回の検討において機能性発声障害を発声 時喉頭所見から type I と type II-Vに二分したことは 妥当であると考えられる.

それぞれの型に使用した音声治療のプロトコールに 関して，前者においては，咳払い，閉口での咳払い， ハミング，そのまま開口という課題を順に遂行するこ とによって持続母音発声の誘導を行った。一方, 後者 においては，八ミング，ピッチ上昇により声の焦点を 鼻根部に意識，焦点を保ったまま開口を連続して通常 の発声を誘導し,無効な場合にはあくび-ため息法を行 つた後に再度誘導を行った．前者の方法は，著者が渉 猟した範囲内ではその方法抢よび治療効果について記 されたものは見つけることはできず，心因性失声症に 対する因習的な音声治療法であると思われた。そのた め, 今回その作用機序について議論することは困難で ある.あくまで推量の域を出ないが，前述のごとく心 因性失声症では咳嗽時には声帯の正中への内転が可能 であり ${ }^{4)}$ ，咳払いという共調運動から徐久に目標の有 響音発声へと近づけていく，いわば被治療者に意識さ せずに回り道をして有響音発声を誘導するものである と思われる。

一方, 後者におけるプロトコールの作用機序に関し

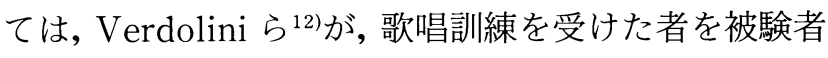
として, 共鳴音発声時の変化について electroglottography 所見および喉頭所見の変化を検討している.

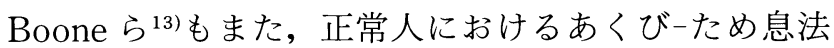
誘導時の変化について咽頭部の CT 所見および音響 分析を用いて検討し, 咽頭腔の拡大とフォルマントの 変化について報告している。これらのことから，これ らの手技の誘導が, 声帯振動, 喉頭の構え, 咽頭腔の 形状に影響を及ぼしているものと考えられる。しかし ながら，これらの音声治療手技が実際の機能性発声障 害症例の病的音声を改善する機序については未解明の 部分が多い. 今後, 音声治療手技誘導中における electroglottography を含むさまざまな所見の即時的 変化の検討により，これらの音声治療手技の作用機序 が明らかになる可能性がある。

今回の検討において，おのおのの型の機能性発声障 害の重症度評価のためにわれわれが使用した「到達度 スコア」と「MTD スコア」は，ともに音声治療経過中 に経時的減少が認められた。前者のスコアに関して， 持続母音発声が不可能な場合には音声所見の評価によ り経時的な変化を捉えることが困難である．到達度ス
コアはこの点において, 音声所見の評価よりも優れて いると考えられた。後者のスコアに関しては，われわ れは過去の報告)において, MTD スコアと同時に音声 所見の知覚的スコアもまた同様に経時的減少を認めた こと, MTD スコアと音声所見との変化量間で相関性 が認められたことを報告している.このことは, MTD スコアによる評価の正当性を示すものである.

これらのスコアの問題点として，評価方法が主観的 であることがある。この点に関して，現在われわれは 発声時喉頭所見画像における喉頭内腔可視面積の計量 による客観的評価を検討中であり, 音声所見について も音響分析による評価の有効性について検討中であ る.しかしながら, 今回用いたこれらの 2 つのスコア による評価法は稚拙ではあるが，いずれも特殊な機器 や, 音声障害診療に精通した複数の評価者を必要とし ないため，どのような医療施設においても施行可能で あるという利点がある。

以上のことから, 機能性音声障害を, 喉頭所見を基 に型別分類し，それぞれに対して異なる音声治療を行 うことは意義があると考えられた。

\section{結語}

1. 機能性音声障害を, Koufman \& Blalockによ る発声時喉頭所見の分類を基に，声門間隙を認めるも のと声門上部圧迫を認めるものに 2 分した。

2. 両者それぞれに対して，異なるプロトコールに て音声治療を行った。

3。それぞれ，異なる簡易なスコアにて評価を行い， ともにスコアの経時的減少が認められた．以上より， 機能性発声障害を型別に分類して音声治療を行う意義 が示された。

謝辞 稿を終えるにあたり，当研究にご助言をいただきまし た城本 修先生に深く感謝の意を捧げます。

なお, 本論文の要旨は第 51 回日本音声言語医学会学術講演会 パネルディスカッション「機能性発声障害の臨床」(2006 年 10 月, 京都) にて発表した.

\section{文献}

1）廣瀬 肇：機能性発声障害. 耳鼻臨床，80：1334-1338, 1987.

2) Koufman JA and Blalock PD: Classification and approach to patients with functional voice disorders. Ann Otol Rhinol Laryngol, 91: 372-377, 1982.

3) Koufman JA and Blalock PD: Functional voice disorders. Otolaryngol Clin North Am, 24: 1059-1073, 1991.

4) Morrison MD and Rammage LA: Muscle misuse voice 
disorders: description and classification. Acta Otolaryngol (Stockh), 113: 428-434, 1993.

5）小川 真, 吉田 操, 渡邊 建, 他: 声門上部圧迫を伴う muscle tension dysphonia における喉頭所見と音声所見と の関連性. 日耳鼻，108：734-741，2005.

6) Kotby MN, El-Sady SR, Basiouny SE, et al: Efficacy of the accent method of voice therapy. J Voice, 5: 316-320, 1991.

7) Roy N and Leeper HA: Effects of the manual laryngeal musculoskeletal tension reduction technique as a treatment for functional voice disorders: Perceptual and acoustic measures. J Voice, 7: 242-249, 1993.

8) Boone DR and MacFarlane SC：音声障害と音声治療（廣 瀬 肇, 藤生雅子訳), 医歯薬出版, 東京, 182-185 頁, 1992.

9) Boone DR and MacFarlane SC：音声障害と音声治療（廣 瀬 肇, 藤生雅子訳), 医歯薬出版, 東京, 195-198 頁, 1992.

10）小川 真, 吉田 操, 渡邊 建, 他：持続母音発声時の内
視鏡下喉頭所見のスコア化による muscle tension dysphonia に対する音声治療の効果の検討. 音声言語医学, 44:292-297, 2003.

11) Stager SV, Bielamowicz S, Regnell JR, et al: Supraglottic activity: evidence of vocal hyperfunction or laryngeal articulation? J Speech Lang Hear Res, 43: 229-236, 2001.

12) Verdolini K, Drucker DG, Palmer PM, et al: Laryngeal adduction in resonance voice. J Voice, 12: 315-327, 1998.

13) Boone DR and McFarlane SC : A critical view of the yawn-sigh as a voice therapy technique. J Voice, 7: 7580, 1993.

別刷請求先：干565-0871 大阪府吹田市山田丘 2 番 2 号 大阪大学大学院耳鼻咽喉科 小川 真 